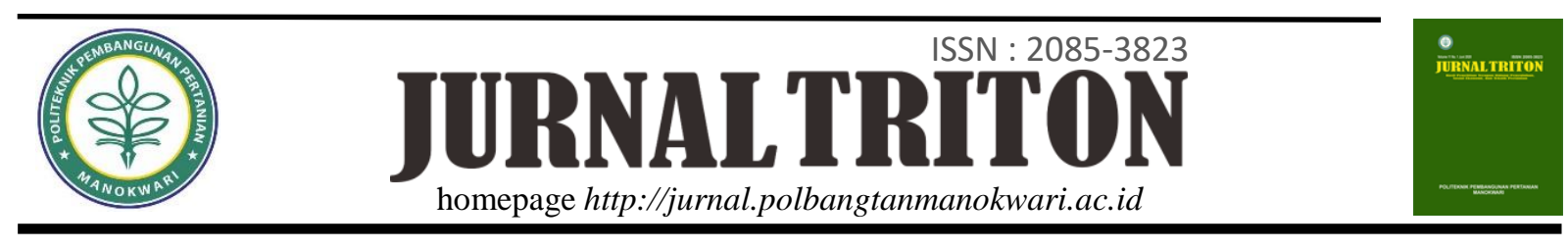

\title{
Pengaruh Pestisida Nabati Jeruk Nipis Berbasis Mikroorganisme Lokal (MOL) terhadap Serangan Hama (Grayak, Belalang, Boleng) dan Bobot Umbi Tanaman Ubi Jalar (Ipomoea batatas L. Lam)
}

Elwin $^{1 *}$, Carolina Diana Mual ${ }^{2}$

${ }^{1,2}$ Prodi Penyuluhan Pertanian Berkelanjutan, Jurusan Pertanian, Politeknik Pembangunan Pertanian Manokwari

\begin{tabular}{l}
\multicolumn{1}{c}{ ARTIKEL INFO } \\
\hline Sejarah artikel \\
Diterima $02 / 06 / 2020$ \\
Diterima dalam bentuk revisi 17/06/2020 \\
Diterima dan disetujui 24/06/2020 \\
Tersedia online 30/06/2020 \\
\hline \\
Kata kunci : \\
Jeruk nipis \\
Mikroorganisme lokal \\
Pestisida nabati \\
\hline
\end{tabular}

\begin{abstract}
ABSTRAK
Ubi jalar (Ipomera batatas L. Lam) merupakan sumber karbohidrat alternatif keempat setelah padi, jagung dan ubi kayu. Akan tetapi pada proses budidayanya masih mengalami kendala utama yaitu serangan hama daun yaitu ulat grayak, belalang dan hama boleng. Serangan hama tersebut menyebabkan turunnya produksi umbi dari tanaman ubi jalar sebesar 10-80\%. Solusi yang dilakukan untuk mengurangi serangan hama selama ini adalah dengan menggunakan pestisida kimia. Akan tetapi pestisida kimia mempunyai efek samping terhadap kesehatan dan juga menyebabkan resistensi hama. Tujuan dari penelitian ini yaitu untuk mengetahui pengaruh pestisida nabati jeruk nipis berbasis mikroorganisme likal (Mol) terhadap serangan hama dan bobo tumbi tanaman ubi jalar. Penelitian ini menggunakan 5 perlakuan yaitu $A_{1}\left(100 \%\right.$ kulit jeruk nupis), $A_{2}$ (100\% air perasan jeruk nipis), $A_{3}$ (25\% kulit jeruk nipis dan $75 \%$ air perasan jeruk nipis), $A_{4}(50 \%$ kulit jeruk nipis dan $50 \%$ air perasan jeruk nipis), dan $\mathrm{A}_{5}$ (75\% kulit jeruk nipis dan $25 \%$ air perasan jeruk nipis). Data hasil penelitian selanjutnya dianalisa menggunakan Analisis Ragam (Anova) metode rancangan acak kelompok nom faktorial dan diuji lanjut dengan menggunakan uji BNT 5\%. Hasil analisa statistik menunjukan bahwa perlakuan berpengaruh nyata terhadap hama pada pengamatan 19 HST, 24 HST, 29 HST dan 34 HST. Akan tetapi perlakluan tidak menunjukan adanya pengaruh yang signifikan terhadap bobot umbi tanaman ubi jalar pada setiap pengamatan.
\end{abstract}

(C) 2020 Politeknik Pembangunan Pertanian Manokwari 


\section{ABSTRACT}

Sweet potato (Ipomera batatas L. Lam) is the fourth alternative source of carbohydrates after rice, corn and cassava. However, the process of cultivation is still experiencing major obstacles which is leaf pest attacks i.e armyworm, grasshopper and boleng pest. The pest attack causes a decrease in tuber production from sweet potato plants by $10-80 \%$. The solution taken to reduce pest attacks so far is by using chemical pesticides. However, chemical pesticides have side effects on health and also cause pest resistance. The objective of this research is to determine the effect of organic pestiside from lime which is based on Local Microorganisme toward

\section{PENDAHULUAN}

Ubi jalar (Ipomoea batatas L. Lam) merupakan tanaman pangan golongan umbiumbian yang mempunyai potensi besar untuk dikembangkan di Indonesia (Guwet, 2009). Hal tersebut karena ubi jalar merupakan sumber karbohidrat alternatif dimana di Indonesia ubi jalar menjadi sumber karbohidrat keempat setelah padi, jagung dan ubi kayu (Ginting et al, 2014). Pengembangan ubi jalar juga didukung oleh kesesuaian agroklimat ubi jalar dengan iklim tropis di Indonesia sehingga tanaman ubi jalar dapat tumbuh dengan baik (Rahayu, 2016).

Ubi jalar selain mengandung karbohidrat juga mengandung senyawa antioksidan yaitu senyawa antosianin (Husna et al, 2013). Hal tersebut berarti mengkonsumsi ubi jalar selain mengenyangkan juga mampu meningkatkan daya tahan tubuh dari serangan berbagai penyakit akibat senyawa radikal bebas. Selain itu ubi jalar juga merupakan tanaman yang dapat dimanfaatkan dalam upaya diversifikasi produk pangan. Ubi jalar dapat diolah menjadi berbagai macam produk pests and tuber weights of sweet potato plants. This research was conducted by using 5 treatments which were $A_{1}\left(100 \%\right.$ lemon peel), $A_{2}$ (100\% lemon juice), $A_{3}$ (25\% lemon peel and $75 \%$ lemon juice), $A_{4}$ (50\% lemon peel and $50 \%$ lemon juice), dan $A_{5}$ (75\% lemon peel and $25 \%$ lemon juice). The collected data was analysed by using Analysis of Variance (Randomize Group Design) non factorial and continued by BNT 5\%. Data analysed showed that the treatment was significant toward pest on 19 HST, 24 HST, 29 HST and 34 HST. The treatment was not significant toward tuber weights of sweet potatoes plants.

turunan seperti selai, dodol, permen, tape, manisan, asinan, keripik dan olahan lainnya. Keunggulan itulah yang menjadi dasar bahwa upaya pengembangan budidaya ubi jalar menjadi hal yang sangat penting untuk terus dilakukan (Ginting et al, 2014).

Permasalahan utama pada budidaya tanaman ubi lajar adalah serangan berbagai jenis hama yaitu ulat grayak, belalang dan hama boleng (Mual, et al, 2018). Serangan hama pada tanaman ubi jalar menjadi salah satu penyebab turunnya hasil umbi dari tanaman ubi jalar sebesar 10-80\% (Lapinangga, 2018). Untuk mengatasi serangan hama pada proses budidaya tanaman ubi jalar sampai saat ini masih menggunakan insektisida kimia (Lapinangga et al, 2018). Pengendalian dengan insektisida kimia memang efektif akan tetapi menghasilkan umbi ubi jalar yang tidak sehat bagi kesehatan (Suhartini et al, 2017). Gangguan kesehatan tubuh yang dapat dialami akibat penggunaan insektisida sintesis atau kimia yaitu nyeri pada bagian perut, gangguan pada jantung, ginjal, hati, 
mata, bahkan dapat menyebabkan kematian

(Hasanah et al, 2012)

Insektisida nabati merupakan metode pengendalian serangga yang dapat diterapkan pada tanaman ubi jalar dan dapat menghasilkan ubi jalar yang sehat. Ubi jalar yang dihasilkan dengan pengendalian secara alami akan meningkatkan minat beli masyarakat sehingga dapat dijual dengan harga yang lebih tinggi. Insektisida nabati dapat mengendalikan hama dan penyakit dengan cara kerja merusak perkembanggan larva, mengurangi nafsu makan, menghambat sistem reproduksi serangga dan mengusir serangga (Tarigan et al, 2012).

\section{METODE}

\section{Waktu dan Tempat}

Penelitian ini dilakukan di lahan Pratik Andai dan laboratorium pertanian Polbangtan Manokwari. Penanaman ubi jalar dilakukan di lahan praktik Andai Polbangtan Manokwari dan pembuatan pestisida nabati dilakukan di laboratorium pertanian Polbangtan Manokwari. Waktu pelaksanaan penelitian ini yaitu bulan Agustus sampai dengan Desember 2019.

\section{Alat dan Bahan}

Alat yang digunakan pada penelitian ini yaitu meteran, cangkul, sekop singkal, rotary, gunting stek, baskom, topless, selang kecil, sprayer, gelas ukur, pemeras jeruk, tali rapiah dan pisau. Bahan yang digunakan yaitu jeruk nipis, gula merah, tepung beras, pupuk kandang dan bibit ubi jalar.

\section{Pelaksanaan Penelitian}

\section{Persiapan lahan}

Persiapan lahan dilakukan dengan membersihkan lahan kemudian membajak lahan menggunakan singkal dan rotari. Tujuan dari pengolahan lahan ini adalah untuk menggemburkan tanah sehingga mempermudah dalam proses pembuatan bedengan. Persiapan lahan dilakukan pada 25 September 2019 sampai 17 oktober 2019.

\section{Pembuatan Bedengan}

Bedengan ubi jalar dibuat dengan tinggi $60 \mathrm{~cm}$, lebar $150 \mathrm{~cm}$ dan panjang 200 $\mathrm{cm}$. Pada penelitian ini terdapat 5 perlakuan dan 1 kontrol dengan 3 kali ulangan. Sehingga terdapat sebanyak 18 petak percobaan dengan jarak antar petak $80 \mathrm{~cm}$. Pada setiap petak ditentukan petak untuk setiap perlakuan secara random. Selanjutnya diberi label perlakuan.

\section{Penanaman}

Ubi jalar yang digunakan adalah ubi jalar lokal yang bibitnya didapatkan dari masyarakat. Bibit ubi jalar yang digunakan yaitu stek dengan panjang bibit $25 \mathrm{~cm}$. Bibit ubi jalar tesebut selanjutnya ditanam pada petak bedengan yang telah disiapkan dengan menanam dua stek setiap lubang tanam. Jarak antar lubang tanam yaitu sebesar $40 \mathrm{~cm}$ dengan jumlah 16 lobang tanam setiap petak bedengan. Setiap bedengan selanjutnya diberi pupuk kandang sebanyak $6 \mathrm{~kg} /$ petak.

\section{Pembuatan Pestisida Nabati}

Penelitian ini menggunakan 5 perlakuan yaitu $A_{1}(100 \%$ kulit jeruk nipis), $\mathrm{A}_{2}$ (100\% air jeruk nipis), $\mathrm{A}_{3}$ ( $25 \%$ kulit jeruk nipis dan $75 \%$ air jeruk nipis), $\mathrm{A}_{4}(50 \%$ kulit jeruk nipis dan $50 \%$ air jeruk nipis), $\mathrm{A}_{5}$ ( $75 \%$ kulit jeruk nipis dan 25\% air jeruk nipis). 
Setiap perlakuan tersebut ditambahkan dengan 50 gram gula merah dan $1000 \mathrm{ml}$ airleri (cucian beras). Air cucian beras dibuat dengan mencampur 100 gram tepung beras dengan $1000 \mathrm{ml}$ air supaya bahan air cucian beras dapat seragam. Campuran bahan kemudian dimasukan ke dalam topless dan ditutup rapat sehingga kondisinya kedap udara atau anaerob. Pada tutup toples dibuat lobang untuk menempatkan selang aliran udara. Ujung selang dihubungkan ke botol yang fungsinya menangkap $\mathrm{CO}_{2}$ dari proses fermentasi yang dilakukan oleh mikroba. Fermentasi dilakukan selama 14 hari selanjutnya pestisida nabati siap untuk diaplikasikan.

\section{Aplikasi Pestisida Nabati}

Pestisida nabati diaplikasikan ke tananam ubi jalar dengan menggunakan sprayer. Perbandingan pestisida nabati dengan air yaitu 1:10 yaitu $100 \mathrm{ml}$ pestisida nabati untuk $1000 \mathrm{ml}$ air. Pestisida nabati disemprotkan ke tanaman ubi jalar 10 hari setelah tanam. Penyemprotan dilakukan setiap 3 hari sekali.

\section{Pengamatan dan Analisa Data}

Parameter yang diamati pada penelitian ini yaitu persentase daun yang rusak karena terserang hama dan berat umbi hasil panen. Persentase daun yang rusak didapatkan dengan membagi jumlah daun yang rusak karena terserang hama dengan total semua daun kemudian dikalikan $100 \%$. Berat umbi didapatkan dengan menimbang bobot umbi untuk setiap perlakuan dengan menggunakan timbangan duduk. Data hasil penelitian selanjutnya dianalisa menggunakan Analisis Ragam Rancangan Acak Kelompok Non Faktorial dan dilakukan uji lanjut dengan menggunakan uji BNT taraf $5 \%$.

\section{HASIL DAN PEMBAHASAN}

\section{Persentase Daun Rusak}

\section{Hari Setelah Tanam (HST)}

Tabel 1. Presentase Daun Rusak 14 HST

\begin{tabular}{lcc}
\hline \hline Perlakuan & $\begin{array}{c}\text { Rata-Rata } \\
\text { Daun } \\
\text { Rusak (\%) }\end{array}$ & Simbol \\
\hline Kontrol & 52 & $\mathrm{a}$ \\
$\mathrm{A}_{1}$ & 28 & $\mathrm{a}$ \\
$\mathrm{A}_{2}$ & 37 & $\mathrm{a}$ \\
$\mathrm{A}_{3}$ & 48 & $\mathrm{a}$ \\
$\mathrm{A}_{4}$ & 52 & $\mathrm{a}$ \\
$\mathrm{A}_{5}$ & 11 & $\mathrm{a}$ \\
\hline
\end{tabular}

Persentase jumlah daun yang rusak tertinggi yaitu pada perlakuan $\mathrm{A}_{0}$ (kontrol) dan perlakuan $\mathrm{A}_{4}$ (50\% kulit jeruk nipis dan $50 \%$ air jeruk nipis) yaitu sebesar $52 \%$. Adapun persentase jumlah daun yang rusak terendah yaitu pada perlakuan $\mathrm{A}_{1}(100 \%$ kulit jeruk nipis) yaitu sebesar 28\%. Secara deskriptif dapat disimpulkan bahwa pada pengamatan 14 HST perlakuan terbaik yaitu perlakuan $\mathrm{A}_{1}$. Akan tetapi setelah dianalisa secara statistik didapatkan nilai signifikasi lebih besar dari 0.05 yang artinya bahwa perlakuan tidak berbeda nyata. Sehingga dapat disimpulkan bahwa pada pengamatan 14 HST perlakuan pestisida jeruk nipis terhadap serangan hama ulat grayak pada tanaman ubi jalar tidak berbeda nyata atau tidak memberikan pengaruh yang signifikan.

Pada pengamatan 14 HST pestisida tidak berpengaruh signifikan terhadap serangan hama. Hal tersebut diduga karena 
pada umur 14 HST jumlah daun tanaman ubi jalar masih sedikit sehingga masih belum banyak yang diserang hama.

\section{Hari Setelah Tanam (HST)}

Tabel 2. Presentase Daun Rusak 19 HST

\begin{tabular}{lcc}
\hline \hline Perlakuan & $\begin{array}{c}\text { Rata-Rata } \\
\text { Daun } \\
\text { Rusak }(\%)\end{array}$ & Simbol \\
\hline Kontrol & 25 & $\mathrm{~b}$ \\
$\mathrm{~A}_{1}$ & 14 & $\mathrm{a}$ \\
$\mathrm{A}_{2}$ & 24 & $\mathrm{~b}$ \\
$\mathrm{~A}_{3}$ & 15 & $\mathrm{a}$ \\
$\mathrm{A}_{4}$ & 21 & $\mathrm{~b}$ \\
$\mathrm{~A}_{5}$ & 11 & $\mathrm{a}$ \\
\hline
\end{tabular}

Persentase jumlah daun yang rusak tertinggi yaitu pada perlakuan $\mathrm{A}_{0}$ (kontrol) yaitu sebesar 25\%. Adapun persentase jumlah daun yang rusak terendah yaitu pada perlakuan $\mathrm{A}_{5}(75 \%$ kulit jeruk nipis dan $25 \%$ air jeruk nipis). Secara deskriptif dapat disimpulkan bahwa pada pengamatan 19 HST perlakuan terbaik yaitu perlakuan $\mathrm{A}_{5}$ dimana dengan rendahnya persentase daun yang rusak menandakan bahwa pestisida jeruk nipis pada perlakuan $A_{5}$ mampu bekerja efektif dalam mengusir hama pada tanaman ubi jalar. Hal ini juga didukung oleh hasil analisa statistik nilai signifikasi lebih kecil dari 0.05 yang artinya bahwa perlakuan berbeda nyata, sehingga dapat disimpulkan bahwa pada pengamatan 19 HST perlakuan pestisida jeruk nipis berpengaruh dalam mengurangi serangan hama.

Pada pengamatan 19 HST perlakuan pestisida nabati berpengarih signifikan. Hal ini diduga karena pada 19 HST hama sudah mulai banyak dan pemberian pestisida nabati mampu mengusir hama yang mulai menyerang tanaman ubi jalar.

\section{Hari Setelah Tanam (HST)}

Tabel 3. Presentase Daun Rusak 24 HST

\begin{tabular}{lcc}
\hline \hline Perlakuan & $\begin{array}{c}\text { Rata-Rata } \\
\text { Daun } \\
\text { Rusak (\%) }\end{array}$ & Simbol \\
\hline Kontrol & 28 & $\mathrm{bc}$ \\
$\mathrm{A}_{1}$ & 18 & $\mathrm{ab}$ \\
$\mathrm{A}_{2}$ & 25 & $\mathrm{abc}$ \\
$\mathrm{A}_{3}$ & 30 & $\mathrm{c}$ \\
$\mathrm{A}_{4}$ & 16 & $\mathrm{a}$ \\
$\mathrm{A}_{5}$ & 16 & $\mathrm{a}$ \\
\hline
\end{tabular}

Persentase jumlah daun yang rusak tertinggi yaitu pada perlakuan $\mathrm{A}_{0}$ (kontrol) yaitu sebesar 28\%. Adapun persentase jumlah daun yang rusak terendah yaitu pada perlakuan $A_{1}$ (100\% kulit jeruk nipis) sebesar 18 persen. Secara deskriptif dapat disimpulkan bahwa pada pengamatan 24 HST perlakuan terbaik yaitu perlakuan $A_{1}$ dengan presentase jumlah daun rusak terendah. Pada pengamatan 24 HST perlakuan pestisida nabati berpengaruh signifikan. Pada 24 HST diduga hama masih terus berdatangan menyerang daun tanaman ubi jalar. Dilihat pada tanaman ubi jalar berbeda nyata atau memberikan pengaruh yang signifikan. Dari persentase kerusakan daun, perlakuan $\mathrm{A}_{4}$ dan $\mathrm{A}_{5}$ memiliki persentase kerusakan yang kecil. Hal ini menunjukan bahwa semakin tinggi kosentrasi kulit jeruk nipis maka semakin efektif dalam menekan serangann hama. 


\section{Hari Setelah Tanam (HST)}

Tabel 4. Presentase Daun Rusak 29 HST

\begin{tabular}{lcc}
\hline Perlakuan & $\begin{array}{c}\text { Rata-Rata } \\
\text { Daun } \\
\text { Rusak }(\%)\end{array}$ & Simbol \\
\hline Kontrol & 31 & $\mathrm{~b}$ \\
$\mathrm{~A}_{1}$ & 17 & $\mathrm{ab}$ \\
$\mathrm{A}_{2}$ & 24 & $\mathrm{ab}$ \\
$\mathrm{A}_{3}$ & 24 & $\mathrm{ab}$ \\
$\mathrm{A}_{4}$ & 18 & $\mathrm{ab}$ \\
$\mathrm{A}_{5}$ & 13 & $\mathrm{a}$ \\
\hline
\end{tabular}

Persentase jumlah daun yang rusak tertinggi yaitu pada perlakuan $\mathrm{A}_{0}$ (kontrol) yaitu sebesar $31 \%$. Adapun persentase jumlah daun yang rusak terendah yaitu pada perlakuan $\mathrm{A}_{5}$ (75 kulit jeruk nipis dan $25 \%$ air jeruk nipis) sebesar $13 \%$. Secara deskriptif dapat disimpulkan bahwa pada pengamatan 29 HST perlakuan terbaik yaitu perlakuan $\mathrm{A}_{5}(16 \%)$ dimana dengan rendahnya persentase daun yang rusak menandakan bahwa pestisida jeruk nipis pada perlakuan $\mathrm{A}_{5}$ efektif dalam mengusir hama ulat grayak. Hal ini juga didukung oleh hasil analisa statistik signifikasi lebih kecil dari 0.05 yang artinya bahwa perlakuan berbeda nyata, sehingga dapat disimpulkan bahwa pada pengamatan 29 HST perlakuan pestisida jeruk nipis terhadap serangan hama ulat grayak pada tanaman ubi jalar berbeda nyata atau memberikan pengaruh yang signifikan.

Pada pengamatan 29 HST pestisida nabati masih memberikan pengaruh yang signifikan dengan intensitas serangan hama terendah yaitu pada perlakuan $\mathrm{A}_{5}$ yaitu sebesar 18\%. Temuan ini memperkuat asumsi bahwa semakin tinggi kosentrasi kulit jeruk nipis maka efektifitas dalam menekan serangan hama semakin besar.

\section{Hari Setelah Tanam (HST)}

Tabel 5. Presentase Daun Rusak 34 HST

\begin{tabular}{lcc}
\hline \hline Perlakuan & $\begin{array}{c}\text { Rata-Rata } \\
\text { Daun } \\
\text { Rusak (\%) }\end{array}$ & Simbol \\
\hline Kontrol & 31 & $\mathrm{~b}$ \\
$\mathrm{~A}_{1}$ & 17 & $\mathrm{ab}$ \\
$\mathrm{A}_{2}$ & 22 & $\mathrm{ab}$ \\
$\mathrm{A}_{3}$ & 23 & $\mathrm{ab}$ \\
$\mathrm{A}_{4}$ & 17 & $\mathrm{ab}$ \\
$\mathrm{A}_{5}$ & 14 & $\mathrm{a}$ \\
\hline
\end{tabular}

Persentase jumlah daun yang rusak tertinggi yaitu pada perlakuan $\mathrm{A}_{0}$ (kontrol) yaitu sebesar $31 \%$. Adapun persentase jumlah daun yang rusak terendah yaitu pada perlakuan $\mathrm{A}_{5}$ (75 kulit jeruk nipis dan $25 \%$ air jeruk nipis) sebesar 14 persen. Secara dekriptif kita dapat menyimpulkan bahwa pada pengamatan 29 HST perlakuan terbaik yaitu perlakuan $\mathrm{A}_{5}$ dimana dengan rendahnya persentase daun yang rusak menandakan bahwa pestisida jeruk nipis pada perlakuan $\mathrm{A}_{5}$ efektif dalam mengusir hama ulat grayak. Hal ini juga didukung oleh hasil analisa statistik nilai signifikasi lebih kecil dari 0.05 yang artinya bahwa perlakuan berbeda nyata, sehingga dapat disimpulkan bahwa pada pengamatan 29 HST perlakuan pestisida jeruk nipis terhadap serangan hama pada tanaman ubi jalar berbeda nyata atau memberikan pengaruh yang signifikan.

Intensitas serangan hama terhadap tanaman ubi jalar diduga masih tinggi sampai pengataman 34 HST terlihat perlakukan pestisida nabati masih memberikan pengaruh yang signifikan. Perlakuan $\mathrm{A}_{5}$ tetap menjadi perlakuan dengan intensitas serangan hama terendah. 


\section{Hari Setelah Tanam (HST)}

Tabel 6. Presentase Daun Rusak 39 HST

\begin{tabular}{lcc}
\hline \hline Perlakuan & $\begin{array}{c}\text { Rata-Rata } \\
\text { Daun } \\
\text { Rusak }(\%)\end{array}$ & Simbol \\
\hline Kontrol & 32 & $\mathrm{a}$ \\
$\mathrm{A}_{1}$ & 17 & $\mathrm{a}$ \\
$\mathrm{A}_{2}$ & 21 & $\mathrm{a}$ \\
$\mathrm{A}_{3}$ & 24 & $\mathrm{a}$ \\
$\mathrm{A}_{4}$ & 18 & $\mathrm{a}$ \\
$\mathrm{A}_{5}$ & 14 & $\mathrm{a}$ \\
\hline
\end{tabular}

Persentase jumlah daun yang rusak tertinggi yaitu pada perlakuan $\mathrm{A}_{0}$ (kontrol) yaitu sebesar 32\%. Adapun persentase jumlah daun yang rusak terendah yaitu pada perlakuan $\mathrm{A}_{5}$ (75 kulit jeruk nipis dan 25\% air jeruk nipis) sebesar 14 persen. Secara dekriptif kita dapat menyimpulkan bahwa pada pengamatan 29 HST perlakuan terbaik yaitu perlakuan $A_{5}$ dimana dengan rendahnya persentase daun yang rusak menandakan bahwa pestisida jeruk nipis pada perlakuan $\mathrm{A}_{5}$ mampu bekerja efektif dalam mengusir hama ulat grayak. Akan tetapi setelah dianalisa secara statistik didapatkan nilai signifikasi lebih besar dari 0.05 yang artinya bahwa perlakuan tidak berbeda nyata, sehingga dapat disimpulkan bahwa pada pengamatan 29 HST perlakuan pestisida jeruk nipis terhadap serangan hama ulat grayak pada tanaman ubi jalar tidak berbeda nyata atau tidak memberikan pengaruh yang signifikan.

Pada pengamatan 39 HST perlakuan pesisida nabati sudah tidak memberikan pengaruh yang signifikan. Hal ini diduga karena pada 39 HST mikorba pada pestisida sudah memasuki masa stasioner sehingga tidak mampu menghasilkans metabolit sekunder yang dapat mengusir hama. Selain itu diduga juga karena pada 39 HST senyawa pada pestisida nabati sudah mulai menguap sehingga menyebabkan turunnya kemampuan pestisida dalam mengusir hama.

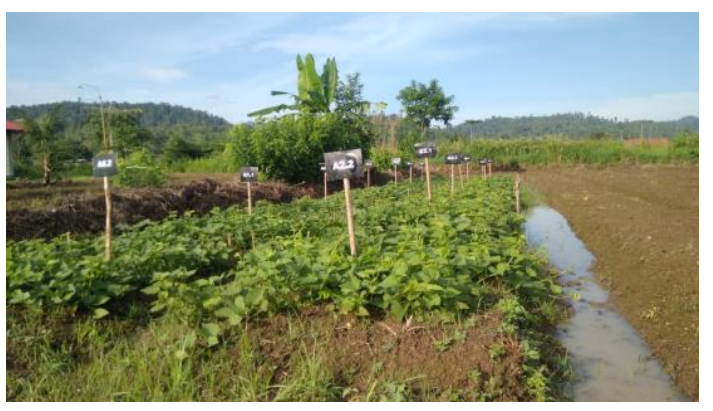

Gambar 1. Petak Pengamatan Penelitian

\section{Bobot Umbi Ubi Jalar}

Tabel 7. Bobot Umbi Ubi Jalar

\begin{tabular}{lcc}
\hline \hline Perlakuan & $\begin{array}{c}\text { Rata-Rata } \\
\text { Bobot } \\
\text { Umbi }(\mathrm{Kg})\end{array}$ & Simbol \\
\hline Kontrol & 3 & $\mathrm{a}$ \\
$\mathrm{A}_{1}$ & 5,2 & $\mathrm{a}$ \\
$\mathrm{A}_{2}$ & 5,7 & $\mathrm{a}$ \\
$\mathrm{A}_{3}$ & 5,5 & $\mathrm{a}$ \\
$\mathrm{A}_{4}$ & 4,3 & $\mathrm{a}$ \\
$\mathrm{A}_{5}$ & 3,9 & $\mathrm{a}$ \\
\hline
\end{tabular}

Hasil analisis ragam (Anova) untuk parameter bobot umbi ubi jalar mendapatkan nilai signifikasi $(\mathrm{P})$ lebih besar dari 0.05 yang berarti bahwa perlakuan tidak memberikan pengaruh yang signifikan terhadap berat umbi ubi jalar. Hal ini diduga karena kerusakan daun pada tanaman ubi jalar akibat serangan hama pada penelitian ini masih pada kisaran 20-30\% dimana jumlah kerusakaan tersebut tidak mempengaruhi proses fotosintesis dalam pembentukan umbi pada tanaman ubi jalar.

\section{KESIMPULAN DAN SARAN}

Perlakuan pestisida nabati mol jeruk nipis terhadap tanaman ubi jalar pada pengamatan 14 HST dan 39 HST tidak memberikan pengaruh yang signifikan 
terhadap serangan hama. Perlakuan pestisida nabati mol jeruk nipis berpengaruh signifikan terhadap serangan hama pada 19 HST, 24 HST, 29 HST dan 34 HST. Perlakuan insektisida nabati mol jeruk nipis tidak memberikan pengaruh yang signifikan terhadap parameter bobot umbi ubi jalar. Saran untuk penelitian selanjutnya perlu dilakukan penelitian lanjutan terhadap varietas ubi jalar yang berbeda dengan menggunakan perlakuan terbaik dari penelitian ini yaitu perlakuan $\mathrm{A}_{5}(75 \%$ kulit jeruk nipis dan $25 \%$ air jeruk nipis).

\section{UCAPAN TERIMA KASIH}

Peneliti mengucapkan terimakasih kepada Polbangtan Manokwari dan Kementerian Pertanian yang telah memberikan bantuan dana penelitian kepada peneliti. Semoga ke depannya dapat kembali melakukan penelitian dengan hasil yang lebih baik lagi.

\section{DAFTAR PUSTAKA}

Ginting, E., Yulifianti, R., \& Jusuf, M. (2014). Ubi Jalar Sebagai Bahan Diversifikasi Pangan Lokal. Balai Penelitian Tanaman Aneka Kacang dan Umbi : Malang

Guwet, H.W. (2009). Karakteristik Ukuran Umbi dan Bentuk Umbi Plasma Nutfah Ubi Jalar. Balitan Plasma Nutfah, 9(2).

Hasanah, M., Tangkas, I.M., dan Sakung, J. (2012). Daya Insektisida Alami Kombinasi Perasan Umbi Gadung (Dioscorea bispida dennst) dan Ekstrak Tembakau (Nicotiana tabacum L). Jurnal Akademik Kimia, (4), 166-173.
Husna, N.E., Novita, M., \& Rohaya, S. (2103). Kandungan Antosianin dan Aktivitas Antioksidan Ubi Jalar Ungu Segra dan Produk Olahannya. Jurnal Agritech, (33), 296-302.

Inrianti \& Paling, S. (2018). Penggunaan Mikroorganisme Lokal (Mol) Daun Sirih Merah (Piper Porphyrophyllum N.E.Br.) dan Biji Srikaya (Annona Squamosa L.) Untuk Mengendalikan Invasi Kepik Hitam (Paraeucosmetus pallicornis dallas) Pada Tanaman Padi. Jurnal Stigma, (2), 17-28.

Lapinangga, J.L., \& Lopez, Y. F. (2018). Pemanfaatan Bahan Nabati Lokal Berefek Pestisida Untuk Mengendalikan Hama Cylas formicarius pada Tanaman Ubi Jalar. Junral Agrovivor, 11(1), 34-38.

Mual, C.D., \& Wati, C. (2018). Intensitas Serangan Hama Penyakit Ubi Jalar (Ipomea batatas Lamb) Sistim Pertanian Lokal Agroekosistem Dataran Rendah di Kabupaten Manokwawi Provinsi Papua Barat. Manokwari: UPPM Politeknik Pembangunan Pertanian Manokwari.

Rahayu, S \& Tamtomo, F. (2016). Efektivitas Mikroorganisme Lokal (MOL) Dalam Meningkatkan Kualitas Kompos, Produksi dan Efisiensi Pemupukan N, P, K Pada Tanaman Ubi Jalar (Ipomea batatas L.). Jurnal Agrosains, (13), 21 29.

Suhartini, Suyadarma, I.G.P., \& Budiwari. (2017). Pemanfaatan Pestisida Nabati Pada Pengendalian Hama Plutella xylostella Tanaman Sawi (Brassica juncea L.) Menuju Pertanian Ramah Lingkungan. Jurnal Sience Dasar, (1), 36-43.

Suhastyo, A.A., Anas, I., Santosa, D.D., \& Lestari, Y. (2013). Studi Mikrobiologi dan Sifat Kimia Mikroorganisme Lokal (MOL) Yang Digunakan Pada Budidaya Padi Metode SRI (System of Rice Intensification). Jurnal Sainteks, (2), 29-39. 
Tarigan, R., Tarigan, M.U., \& Oemry, S. (2012). Uji Afektifitas Larutan Kulit Jeruk Manis dan Larutan Daun Nimba Untuk Mengendalikan Spodoptera Litura F. (Lepidoptera:Moctuidae) Pada Tanaman Sawi Di Lapangan. Jurnal Online Agroekoteknologi, (1), 172-182. 